\title{
Natural convection drying kinetics of 'Prata' and 'D'água' banana cultivars (Musa ssp) by nonlinear regression models
}

\author{
Thais Destefani Ribeiro Furtado ${ }^{1}$, Joel Augusto Muniz², Edilson Marcelino Silva ${ }^{3}$, \\ Ariana Campos Frühauf ${ }^{4}$,Tales Jesus Fernandes ${ }^{5}$
}

\begin{abstract}
Banana is among fruits most planted in tropical countries and belongs to the fruit group most consumed in the world; however, banana needs proper conservation techniques. The aim of this study was to describe the drying kinetics of 'Prata' and ' $D$ 'água' banana cultivars at temperatures of 40 and $70^{\circ} \mathrm{C}$, comparing the Henderson, STPE, Lewis, Page and Fick regression models, estimating the Absolute Drying Rate (ADR). Parameters were estimated with $\mathrm{R}$ and SAS Studio softwares, using for comparison and selection models of the $\mathrm{R}^{2}{ }_{\mathrm{aj}}$, RSD and corrected Akaike Information Criteria. The Page and Fick models did not adjust, and the others presented good adjustment to data. The Henderson model was the most suitable to describe data of 'Prata' banana at both temperatures and 'D'água' banana at $70^{\circ} \mathrm{C}$ and Lewis at $40^{\circ} \mathrm{C}$ for this cultivar. The drying rate of 'Prata' banana at temperatures of 40 and $70^{\circ} \mathrm{C}$ were $0.00079 \mathrm{~g}$ of water/ min and $0.00400 \mathrm{~g}$ of water/min respectively and for ' $\mathrm{D}$ 'água' banana, drying rates were $0.00111 \mathrm{~g}$ of water $/ \mathrm{min}$. and $0.00495 \mathrm{~g}$ of water/min., respectively. Using ADR, it was observed that in one third of the drying period, there was $70 \%$ of moisture loss at $70^{\circ} \mathrm{C}$.

Index terms: Food preservation; Absolute Drying Rate; Estimation; Statistical models.

\section{Cinética de secagem em convecção natural de bananas Prata e D’água (Musa ssp) por modelos de regressão não linear}

Corresponding author: t.destefani.ribeiro@gmail.com

Received: January 23, 2019 Accepted: August 02, 2019

Copyright: All the contents of this journal, except where otherwise noted, is licensed under a Creative Commons Attribution License.

\section{(cc) $\mathbf{E Y}$}

Resumo-A bananeira está entre as frutíferas mais plantadas em países tropicais e pertence ao grupo de frutos mais consumidos do mundo; entretanto, necessitam de técnicas de conservação adequadas. Objetivou-se descrever a cinética de secagem de bananas Prata e D'água nas temperaturas de $40 \mathrm{e}$ $70^{\circ} \mathrm{C}$, comparando os modelos de regressão Henderson, ESTP, Lewis, Page e Fick, estimando-se a Taxa de Secagem Absoluta (TSA). Os parâmetros foram estimados com os softwares R e SAS Studio, utilizando-se para comparação e seleção de modelos R $_{\text {aj }}$, DPR e Critério de Informação de Akaike corrigido. Os modelos de Page e Fick não se ajustaram, e os demais apresentaram bom ajuste aos dados. O modelo de Henderson foi o mais indicado para descrever os dados de bananaPrata em ambas as temperaturas e banana D'água em $70^{\circ} \mathrm{C}$ e o de Lewis para a temperatura de $40^{\circ} \mathrm{C}$ desta cultivar. A taxa de secagem da banana-Prata, nas temperaturas de 40 e $70^{\circ} \mathrm{C}$, foram de $0,00079 \mathrm{~g}$ de água/min e $0,00400 \mathrm{~g}$ de água/min, respectivamente, e para banana D'água foram de $0,00111 \mathrm{~g}$ de água/min e $0,00495 \mathrm{~g}$ de água/min, respectivamente. Com a TSA, observou-se que em um terço do período de secagem houve $70 \%$ da perda de umidade aos $70^{\circ} \mathrm{C}$.

Termos para indexação: Conservação de alimentos; Taxa de Secagem Absoluta; Estimação; Modelos estatísticos.

${ }^{1} \mathrm{PhD}$ in Statistics and Agricultural Experimentation, Federal University of Lavras, Lavras-MG, Brazil. Email: t.destefani.ribeiro@gmail. com ${ }^{\text {ORCID } 0000-0002-6402-5202)}$

${ }^{2} \mathrm{PhD}$ in Statistics and Agronomic Experimentation, Professor at the Federal University of Lavras, Lavras-MG, Brazil. Email: joamuniz@ des.ufla.br(ORCID 0000-0002-1069-4136)

${ }^{3}$ Doctoral student in Statistics and Agricultural Experimentation, Federal University of Lavras, Lavras-MG, Brazil. E-mail:edilsonmg3@ hotmail.com (ORCID 0000-0002-2800-3495)

${ }^{4}$ Doctoral Student in Statistics and Agricultural Experimentation, Federal University of Lavras, Lavras-MG, Brazil. E-mail:arianafruhauf@ gmail.com (ORCID 0000-0001-5759-7758)

${ }^{5} \mathrm{PhD}$ in Statistics and Agronomic Experimentation, Professor at the Federal University of Lavras, Lavras-MG, Brazil. E-mail: tales.jfernandes@ des.ufla.br ${ }^{\text {(ORCID } 0000-0002-1457-9653)}$ 


\section{Introduction}

Most banana cultivars originated in Asia, with some cultivars originating in Africa and Pacific Ocean islands. They are typically tropical plants that require constant heat and high humidity for their natural development (BORGES et al., 2006). According to Salomão et al. (2016), banana (Musa spp) is among the fruit trees most planted in tropical countries and in Brazil, its cultivation generates significant number of jobs, representing an important source of income for producers, positively affecting the country's economy.

The countries with the largest banana production in the order are India, China, Brazil and Indonesia. The annual Brazilian banana production is over 6.7 million tonnes in an area of approximately 470 thousand hectares, destined for domestic supply, considering the high per capita consumption of $60 \mathrm{~kg}$ / person / year (FAOSTAT, 2018). Brazil also exports its excess production of 41 thousand tons mainly to Argentina and Uruguay. The Brazilian states with the highest production are in the order SP, BA, SC and MG, with emphasis on 'Nanica', 'Prata' and 'Maçã' cultivars, among others (IBGE, 2018).

Bananas are among the fruits most consumed in the world, whether processed, fried, cooked or even fresh (NOMURA et al., 2013), which has great food importance because it is a fruit rich in carbohydrates, calcium, magnesium, potassium, vitamin $\mathrm{A}$ and other minerals (BORGES et al., 2006; TBCA, 2018). In the fresh form, it is an extremely perishable fruit and its marketing requires adequate logistics to be performed quickly and rationally. Post-harvest fruit management requires special care to minimize losses and maintain product quality so that it reaches the consumer perfectly. Banana quality is extremely important for both export and domestic market, considering that product pricing takes this aspect into account (COSTA, AUGUSTO, REGO, 2014; SALOMÃO et al., 2016). Therefore, the use of harvest and post-harvest banana conservation technologies are strategies to assist producers, enabling the expansion of production volume and increasing competitiveness for both domestic and external markets (SANTOS et al., 2017).

The shelf-life of foods in general can be increased by using drying techniques (GONÇALVES et al., 2016). Drying is a practice with several advantages such as low cost and simplicity of use, which allow transforming foods with high water content into dehydrated foods while preserving their main physical and chemical characteristics. The drying process involves the removal of water or other liquids from the food. Among its benefits, reduction of post-harvest loss stands out (CELESTINO, 2010).

Dried banana or raisin banana has high sugar content, being considered a product with high food value and of easy absorption. Among the various forms of consumption, banana raisin consumed pure or used as an ingredient for cakes are preferred by consumers. Acceptance is mainly due to taste, which is much appreciated. However, dry fruit consumption is still small due to the lack of quality control of production processes (MOTA, 2005). In this sense, it is necessary to know and explore drying techniques to improve the quality of the product and consequently promote its consumption.

The study of fruit drying curves can be performed based on the construction of mathematical models that relate moisture content with time. According to Furtado et al. (2019), drying curves are sigmoid and can be described by nonlinear regression models. The authors compared nonlinear Henderson, Lewis, Fick and Thompson models in describing the drying of jabuticaba pulp and concluded that the Lewis model is the most adequate to describe data. Silva et al. (2017) described the cupuassu pulp drying kinetics behavior in biopolymer production using different models that characterize a decreasing growth curve. Araujo et al. (2017) evaluated nonlinear models for the adjustment to drying data of peanuts submitted to different temperatures. In general, nonlinear regression models describe well the drying kinetics processes and obtain parameters with biological interpretation.

The aim of this study was to evaluate the adjustment quality of nonlinear Page, Lewis, Henderson, Simple Three-Parameter Exponential and Fick models in the description of the drying kinetics of 'Prata' and 'D'água' banana cultivars at different temperatures and to estimate the absolute pulp drying rate for the most suitable model.

\section{Material and methods}

Data used in this study were obtained from Borges et al. (2011). 'Prata' and 'D'água' bananas used in the research were purchased at the local market of Lavras-MG and selected considering the degree of uniform ripeness. The raw material was cleaned, peeled and cut into disc shape $(0.005 \mathrm{~cm}$ in thickness and average fruit diameter of $0.035 \pm 0.003 \mathrm{~m})$. The material was submitted to the bleaching process and drying through natural convection at temperatures equal to $40^{\circ} \mathrm{C}$ and $70^{\circ} \mathrm{C}$. Evaluations were performed in triplicate in the same sample composed of the homogenized material. The moisture ratio was observed in the first 8 hours, thereafter every 3 hours and 12 minutes until approximately 24 hours, totaling 14 measurements over time, considering that at time 0 , the moisture ratio is equal to 1 for both temperatures and cultivars.

Nonlinear Lewis (L), Page (P), Henderson (H), Simple Three-Parameter Exponential (STPE) and Fick (F) regression models were adjusted to the set of data, described by respective equations:

$M R_{i}=\exp \left(-k_{1} t_{i}\right)+u_{i}(1) ; M R_{i}=\exp \left(-k_{t} t^{n}\right)+u_{i}(2) ;$
$M R_{i}=k_{0} \exp \left(-k_{l} t_{i}\right)+u_{i}(3) ; M R_{i}=k_{0} \exp \left(-k_{i} t_{i}\right)+k_{2}+u_{i}(4)$ and 


$$
M R_{i}=\frac{6}{\pi^{2}} \sum_{n=1}^{i} \frac{1}{n^{2}} \exp \left(-n^{2} \pi^{2} D_{e f} \frac{1}{t_{i}}\right)+u_{i}
$$

In the expressions of models $u_{i}=\phi_{l} \mathrm{u}_{i-1}+\ldots+\phi_{p} \mathrm{u}_{i-p}+\varepsilon_{i}$ with $i=1,2, \ldots, 14$, being $u_{i}$ the adjustment residue at the i-th time; $\phi_{i}$ the autoregressive parameter of order $i ; u_{i-1}$ the time adjustment residue immediately prior to the $\mathrm{i}$-th measurement; $\phi_{p}$ the autoregressive parameter of order $p ; u_{i-1}$ the adjustment residue in times prior to the i-th measurement; $\varepsilon_{1}$ the white noise residue with normal distribution. In the case of independent residues, parameters $\phi_{i}$ will be null, and thus, $u_{i}=\varepsilon_{l}$ (GUEDES et al., 2004; MAZZINI et al., 2003; MUNIZ et al., 2017; PRADO; SAVIAN; MUNIZ, 2013; RIBEIRO et al., 2018b; SOUZA et al., 2010; SILVEIRA et al., 2011).

In equations (1), (2), (3), (4) and (5), $M R_{i}$ corresponds to the dependent variable, indicating the average value of the banana pulp moisture ratio (dimensionless) in time $i$ in days; $k_{0}$ refers to the initial fruit condition, being close to 1 because it represents $100 \%$ of the initial pulp moisture; $k_{1}$ refers to the drying rate, which can also be obtained by differentiation and refers to the moisture loss variation over the process time, with values between 0 and 1 because moisture loss is always smaller than the drying period; $k_{2}$ corresponds to the dimensionless parameter of the model adjustment; exp is the basis of the neperian logarithm.

The parameter estimation process for the adjustment of nonlinear models generally considers minimizing the sum of squares of residues that leads to a system of normal nonlinear equations requiring the use of iterative methods. Among methods, the most used is the one by Gauss-Newton (SAVIAN; MUNIZ, 2007; ZEVIANI et al., 2012; CARNEIRO et al., 2014; FERNANDES; PEREIRA; MUNIZ, 2015; MUIANGA et al., 2016; MUNIZ et al. al., 2017; FERNANDES et al., 2017; RIBEIRO et al., 2018 a, b; SOUZA et al., 2014; SILVEIRA et al., 2018). Model adjustments were made using the R software (R DEVELOPMENT CORE TEAM, 2017), which uses the Gauss-Newton iterative method and the free-version Statistical Analysis System (SAS STUDIO, 2018).

To validate inferences made, based on the adjusted models, statistical tests and graphs were used to verify the assumptions of independence, normality and homoscedasticity of residues. The Durbin-Watson (DW) test (MORETTIN; TOLOI, 2006) was used to assess the existence of residual autocorrelation, while the ShapiroWilk (SW) (SHAPIRO; WILK, 1965) and Breusch-Pagan (BP) tests (BREUSCH; PAGAN, 1979) were applied to verify the normality and homogeneity of residues, respectively.

In order to evaluate the adjustment quality of models, the adjusted determination coefficient $\left(\mathrm{R}^{2}{ }_{\mathrm{aj}}\right)$ and the residual standard deviation (RSD) were used.
The higher the $\mathrm{R}_{\text {aj }}^{2}$ value, the lower the RSD, the better the model adjustment to data. The corrected Akaike Information Criterion (AIC) was used as model selection criterion (AKAIKE, 1974).

The significance of estimates obtained for the model parameters was tested by applying the Student t-test and then, 95\% confidence intervals were calculated. Finally, the drying curve was studied based on the Absolute Drying Rate (ADR), calculating the first and second derivatives of the most appropriate model, according to Furtado et al. (2019).

\section{Results and discussion}

Firstly, residual analyses were presented for the model adjustments and evaluation of the adjustment quality of models with their practical interpretations, when applicable. The Page and Fick models did not converge at both temperatures and cultivars, as occurred with the Simple Three-Parameter Exponential Model (STPE) for the 'D'água' Banana data at $70^{\circ} \mathrm{C}$, so the results for these models do not appear in tables and figures. Table 1 presents the Shapiro-Wilk, Breusch-Pagan and Durbin-Watson tests, with their respective significance, and Figures 1 and 2 show the residual analysis graphs for the Lewis (L), Henderson $(\mathrm{H})$ and Simple Three-Parameter Exponential Model (STPE) models to the drying kinetic data of 'Prata' and 'D'água' banana cultivars at $40^{\circ} \mathrm{C}$ and $70^{\circ} \mathrm{C}$ except for STPE for 'D'água' cultivar.

The Durbin-Watson test was generally significant, indicating residual autocorrelation at both temperatures for 'Prata' and 'D'água' cultivars, i.e., there was residual dependence over time. This result was expected, as measurements were performed on the same ' $\mathrm{D}$ 'água' and 'Prata' banana material, respectively, over time. In fruit growth studies, similar results were found by PRADO; SAVIAN; MUNIZ, (2013), Muniz et al. (2017), Muianga et al. (2016) and Ribeiro et al. (2018a), who observed the presence of autocorrelated errors in the adjustment of nonlinear regression models to describe the growth of coconut, cacao, cashew and pear fruits, respectively. According to these authors, whenever residual dependence is observed, this correlation should be modeled by an autoregressive process. Different results were found by Ribeiro et al. (2018b) with the growth of pequi fruits, as residual dependence was not observed because biometric measurements were made on different fruits at each age.

After the study on residual dependence, considering the autoregressive errors of orders 1 and / or 2, it was verified that the Shapiro-Wilk and Breusch-Pagan tests were not significant in both temperatures and cultivars, and it could be inferred that the residual values are usually distributed and with homogeneous variance. Similarly, Figures 1 and 2 show that there is no pattern in figures, corroborating results of Table 1 . The verification of 
assumptions for the regression models is important for the validation of estimates obtained, since if not met, the model is said to be unsuitable.

Estimates with $95 \%$ confidence intervals for parameters of the Henderson, Lewis and Simple ThreeParameter Exponential models at temperatures of 40 and $70^{\circ} \mathrm{C}$ for 'Prata' and 'D'água' cultivars are presented in Table 2. Based on the estimates of parameter $k_{0}$ presented in Table 2, it was observed that the values obtained were close to 1 at both temperatures, as expected, as they refer to $100 \%$ of the initial moisture in the banana material. The STPE model at temperature of $40^{\circ} \mathrm{C}$ for 'Prata' cultivar overestimated the expected $k_{0}$ value and still presented wide confidence interval, indicating that the estimate is not reliable. Leite et al. (2015) studied the drying kinetics of slices of 'Terra' banana cultivar and found values close to 1 for the initial moisture content, which in their study, they named "a" for the Midilli model.

Estimates for parameter $k_{1}$ were between 0 and 1, as expected, as they represent the product's drying rate, which is given by the ratio between the moisture variation and the drying time variation. Considering the values observed in Table 2, the drying rates at temperatures $40^{\circ} \mathrm{C}$ and $70^{\circ} \mathrm{C}$ for 'Prata' cultivar averaged 0.00079 $\mathrm{g}$ water / $\mathrm{min}$ and $0.00400 \mathrm{~g}$ water / min respectively, and $0.00111 \mathrm{~g}$ water/min and $0.00495 \mathrm{~g}$ water/min for 'D'água' cultivar. As it can be observed, with temperature increase, $k_{1}$ increases, that is, the moisture loss rate over time is greater with the increase in the drying temperature, corroborating results obtained by Gouveia et al. (2003) with the drying curve of cajá fruits. Temperature is one of the most influential factors in the drying process, and the higher the temperature, the shorter the drying time and, consequently, the faster the equilibrium moisture content (Ue) of the product is reached. Similar results were found by Borges et al. (2008) with the drying kinetics of pumpkin slices and Leite et al. (2015) with the drying of 'Terra' banana cultivar at temperatures of 40 to $60^{\circ} \mathrm{C}$.

Confidence Intervals (CI) for parameter $k_{2}$ of the STPE model in both temperatures and banana cultivars involved the zero value, so this model was considered inadequate to describe data. Parameters $k_{0}$ and $k_{1}$ presented small amplitude CI with only positive values in all temperatures and cultivars, which according to Ribeiro et al. (2018a), very small amplitude intervals indicate adjustment quality of models to data.

According to Muniz et al. (2017) and Ribeiro et al. (2018a), the use of autoregressive errors, when there is residual dependence, has the characteristic of improving the adjustment quality of models, making the estimated values to have greater reliability with more accurate results. For 'Prata' and 'D'água' banana data at $40^{\circ} \mathrm{C}$, the autoregressive components of orders 1 and 2 were considered. Regarding the values estimated for $\emptyset_{1}$ and $\emptyset_{2}$, values were greater than 1 and $\emptyset_{2}$ values were within the $[-1 ; 1]$ range. Observing that $\phi_{2}-\phi_{1}<1$ and $\phi_{1}-\phi_{2}<$
1 , there are indications that the values are in the unitary circle, which is justified by Morettin and Toloi (2006), because under these conditions, there are guarantees of stationarity AR2 data series.

Based on the above, it could be inferred that the drying kinetics data of 'Prata' and 'D'água' banana cultivars are highly correlated at temperature of $40^{\circ} \mathrm{C}$. At $70^{\circ} \mathrm{C}$, data for both cultivars presented residual dependence of order 1 , with confidence intervals free from zero, indicating reliability in the result presented in Table 2, with high correlation. In general, the results indicated a high positive correlation among residues at both temperatures and cultivars, which corresponds to the strong correlation of observations over time, confirming the need to be considered when adjusting models to data.

Table 3 presents the adjustment quality evaluators $\mathrm{R}_{\text {aj, }}^{2}$ RSD, and the AIC selection criterion for models that adjusted to the drying kinetics data of 'Prata' and 'D'água' banana cultivar at temperatures of 40 and $70^{\circ}$ C. The estimated values for the adjusted determination coefficient at temperatures of 40 and $70^{\circ} \mathrm{C}$ were above 0.97 for Henderson models in both cultivars, and those of RSD were low, in the order of $10^{-2}$, indicating satisfactory adjustments; however, the Lewis models presented low $\mathrm{R}^{2}{ }_{\mathrm{aj}}$ values and high RSD values, suggesting lack of adjustment, except at $40^{\circ} \mathrm{C}$ for 'D'água' cultivar. Leite et al. (2015), in studies with the drying kinetic of 'Terra' banana observed $\mathrm{R}^{2}$ values above 0.97 and standard error of $10^{-2}$. Gonçalves et al. (2016) when studying the drying of green banana pulp found $\mathrm{R}^{2}$ values above 0.95 for the Lewis, Page, Henderson and Midilli models. Sari et al. (2019), in studies with tomato growth, found $\mathrm{R}^{2}$ values above 0.96 for nonlinear regression models, and considered adjustment quality.

Considering the AIC selection criteria presented in Table 3, the most suitable model to describe 'Prata' banana kinetic data at 40 and $70^{\circ} \mathrm{C}$ and 'D'água' banana at $70^{\circ} \mathrm{C}$ was the Henderson model, and the Lewis model at $40^{\circ} \mathrm{C}$ for ' $\mathrm{D}$ 'água' cultivar, with lower criterion values . Muniz et al. (2017) and Ribeiro et al. (2018a) used the AIC selection criteria to compare nonlinear regression models in the description of cocoa and pear fruit growth, respectively, and found that lower AIC values indicated the most suitable nonlinear regression model to describe data.

According to results of Table 3, the Henderson model was the most suitable for 'Prata' cultivar at both temperatures and at $70^{\circ} \mathrm{C}$ for ' $\mathrm{D}$ 'água' cultivar, while the Lewis model was the most suitable for ' $D$ 'água' cultivar at $40^{\circ} \mathrm{C}$. Figures 3 and 4 illustrate the drying process of cultivars at both temperatures. At $70^{\circ} \mathrm{C}$, curves were generally steeper, clearly characterizing the four phases involved in the drying process (GOUVEIA et al., 2003). At $40^{\circ} \mathrm{C}$, curves were smoother, impairing the identification of phases, suggesting that further measurements would be needed over time to better visualize stabilization at the end of the last drying phase, reaching the equilibrium 
moisture content.

The drying processes presented in Figures 3 (a) and 4 (a) show that the moisture loss for 'Prata' and 'D'água' cultivars at $40^{\circ} \mathrm{C}$, respectively, decreases more sharply until approximately 600 minutes. From this point, fruits undergo constant and decreasing moisture loss phases until they approach equilibrium moisture stabilization at 1450 minutes. For Cano-Chauca et al. (2004), in studies with raising bananas at the beginning of drying processes, significant part of the moisture is easily removed, and after a certain period, there is greater internal resistance to moisture removal. The authors also consider that, adequate evaluation regarding the moisture content allows the prediction of the ideal times for the drying process.

The drying curves at $70^{\circ} \mathrm{C}$ for 'Prata' and 'D'água' cultivars are shown in Figures 3 (b) and 4 (b), respectively. In general, both cultivars reach equilibrium moisture content within approximately 200 minutes, following the other drying process stages until reaching equilibrium moisture content within 900 minutes, and are observed up to 1450 minutes without significant changes. It is noteworthy that the drying process for 'Prata' cultivar obtained lower mean moisture contents compared to those of 'D'água' cultivar at the end of the process, but even so, presented similar characteristics at both temperatures evaluated and even with an increase of $30^{\circ} \mathrm{C}$ in temperature, there was a considerable decrease in moisture content, as can be seen in Figures 3 and 4. Similar results were obtained by Madureira et al. (2011) with the drying of fig pulp with the addition of modified starch, since with a $10^{\circ} \mathrm{C}$ increase in the drying temperature, there was a decrease of about $30 \%$ in the drying process. Gonçalves et al. (2016) with the drying of green banana pulp, observed that the higher the temperature, the shorter the drying time.

According to Furtado et al. (2019) in the drying phases with constant moisture loss, it was observed that the increase in temperature reduces this phase, indicating that a significant amount of water is in the free form in jabuticaba pulp and the other portion interacts with soluble solids. Similar results were observed in the present study, with the drying kinetics of 'Prata' and 'D'água' banana cultivars, because by raising temperature, fruits reached the equilibrium moisture content faster, optimizing the drying process. However, chemical, physical and biological analyses are required to decide the best drying temperature.

After choosing the most suitable models, Absolute Drying Rates (ADR) were obtained, which can be seen in Figures 5 and 6. It is generally found that at $40^{\circ} \mathrm{C}$ for both cultivars, Figures 5 (a) and 6 (a), there was greater moisture loss in the range from 0 to 700 minutes, even if it occurred mildly, in which during this period, $55 \%$ of the drying process already occurred. After this period, moisture loss decelerated until it approached stabilization at the end of the evaluation period. In (b) of Figures 5 and 6, ADR indicated accelerated moisture loss from 0 to 410 minutes, which represents about one third of the drying period, which represented $72 \%$ of the moisture loss occurred throughout the process, as in (a), there was deceleration in moisture loss after this period until stabilization was reached. Furtado et al. (2019) found similar results with the drying of jabuticaba pulp, where there is a process deceleration until stabilization after the most severe moisture loss. Leite et al. (2015) found that after the final stabilization reaching equilibrium moisture content, moisture loss can only be changed if the process conditions are changed, such as drying air temperature and velocity; the same was verified by Cano-Chauca et al. (2004) when studying banana raisings.

Table 1. Values for the Shapiro-Wilk (SW), Breusch-Pagan (BP) and Durbin-Watson (DW) tests with their respective significance in the analysis of estimated residues after the adjustment of the Lewis (L), Henderson (H) and Simple Three-Parameter Exponential (STPE) models to the drying kinetic data of 'Prata' and 'D'água' banana cultivars at temperatures of $40^{\circ} \mathrm{C}$ and $70^{\circ} \mathrm{C}$.

\begin{tabular}{|c|c|c|c|c|c|c|c|}
\hline \multirow{2}{*}{ Cultivars } & \multirow{2}{*}{ Models } & \multicolumn{3}{|c|}{$40^{\circ} \mathrm{C}$} & \multicolumn{3}{|c|}{$70^{\circ} \mathrm{C}$} \\
\hline & & SW & $\mathrm{BP}$ & DW & SW & $\mathrm{BP}$ & DW \\
\hline \multirow{3}{*}{ 'Prata' } & L AR2 & $0.3710^{\mathrm{NS}}$ & $0.1231^{\mathrm{NS}}$ & $0.3140^{\mathrm{NS}}$ & $0.0997^{\mathrm{NS}}$ & $0.5251^{\mathrm{NS}}$ & $0.3569^{\mathrm{NS}}$ \\
\hline & H AR2 & $0.5689^{\mathrm{NS}}$ & $0.1408^{\mathrm{NS}}$ & $0.0739^{\mathrm{NS}}$ & $0.1768^{\mathrm{NS}}$ & $0.5343^{\mathrm{NS}}$ & $0.2555^{\mathrm{NS}}$ \\
\hline & STPE AR2 & $0.0729^{\mathrm{NS}}$ & $0.0921^{\mathrm{NS}}$ & $0.0640^{\mathrm{NS}}$ & $0.2822^{\mathrm{NS}}$ & $0.9205^{\mathrm{NS}}$ & $0.0821^{\mathrm{NS}}$ \\
\hline \multirow{3}{*}{ 'D’água' } & L & $0.9540^{\mathrm{NS}}$ & $0.8969^{\mathrm{NS}}$ & $0.5021^{\mathrm{NS}}$ & $0.9193^{\mathrm{NS}}$ & $0.2412^{\mathrm{NS}}$ & $0.7209^{\mathrm{NS}}$ \\
\hline & ESDP & $0.9900^{\mathrm{NS}}$ & $0.8434^{\mathrm{NS}}$ & $0.5553^{\mathrm{NS}}$ & $0.9208^{\mathrm{NS}}$ & $0.2415^{\mathrm{NS}}$ & $0.7783^{\mathrm{NS}}$ \\
\hline & STPE & $0.7122^{\mathrm{NS}}$ & $0.4833^{\mathrm{NS}}$ & $0.6569^{\mathrm{NS}}$ & & & \\
\hline
\end{tabular}

${ }^{*}$ Significant at $5 \%$ probability level by respective SW, BP and DW tests.

${ }^{\mathrm{NS}}$ Not significant in relation to respective SW, BP and DW tests. 
Table 2. Estimates of parameters with their respective confidence intervals (LI and LS), Lewis (L), Henderson (H) and Simple Three-parameter Exponential (STPE) to the drying kinetics data of 'Prata' and ' $D$ 'água' banana cultivars at temperatures of $40^{\circ} \mathrm{C}$ and $70^{\circ} \mathrm{C}$, considering autoregressive errors of orders 1 and 2.

\begin{tabular}{|c|c|c|c|c|c|c|c|c|}
\hline \multirow{2}{*}{ Cultivars } & \multirow{2}{*}{ Models } & \multirow{2}{*}{ Parameters } & \multicolumn{3}{|c|}{$40^{\circ} \mathrm{C}$} & \multicolumn{3}{|c|}{$70^{\circ} \mathrm{C}$} \\
\hline & & & Estimates & LL & UL & Estimates & LL & UL \\
\hline \multirow{12}{*}{ 'Prata' } & \multirow{3}{*}{$\mathrm{L}$} & $\mathrm{k}_{1}$ & 0.00076 & 0.00071 & 0.00081 & 0.00390 & 0.00360 & 0.00430 \\
\hline & & $\emptyset_{1}$ & 1.30660 & 1.01330 & 2.14040 & 0.93940 & 0.72290 & 1.31810 \\
\hline & & $\emptyset_{2}$ & -0.75460 & -1.71230 & -0.44530 & - & - & - \\
\hline & \multirow{4}{*}{$\mathrm{H}$} & $\mathrm{k}_{0}$ & 1.01830 & 0.99010 & 1.04670 & 0.96660 & 0.89870 & 1.03450 \\
\hline & & $\mathrm{k}_{1}$ & 0.00079 & 0.00073 & 0.00086 & 0.00400 & 0.00360 & 0.00440 \\
\hline & & $\emptyset_{1}$ & 1.26820 & 0.92400 & 2.14500 & 0.96840 & 0.69370 & 1.30730 \\
\hline & & $\emptyset_{2}$ & -0.79280 & -1.73430 & -0.42610 & - & - & - \\
\hline & \multirow{5}{*}{ STPE } & $\mathrm{k}_{0}$ & 1.37170 & 0.76720 & 6.83160 & 0.95640 & 0.90050 & 1.03030 \\
\hline & & $\mathrm{k}_{1}$ & 0.00051 & 0.00008 & 0.00113 & 0.00411 & 0.03385 & 0.00443 \\
\hline & & $\mathrm{k}_{2}$ & -0.36790 & -5.83440 & 0.23520 & 0.04550 & -0.03440 & 0.10180 \\
\hline & & $\emptyset_{1}$ & 1.58610 & 0.91620 & 2.32250 & 0.59110 & -0.05500 & 1.18120 \\
\hline & & $\emptyset_{2}$ & -1.38670 & -2.57280 & -0.50340 & - & & \\
\hline \multirow{12}{*}{ 'D’água' } & \multirow{3}{*}{$\mathrm{L}$} & $\mathrm{k}_{1}$ & 0.00111 & 0.00105 & 0.00117 & 0.00498 & 0.00478 & 0.00518 \\
\hline & & $\emptyset_{1}$ & 1.1544 & 0.5960 & 1.8421 & 0.6438 & 0.1378 & 1.1389 \\
\hline & & $\emptyset_{2}$ & -0.6463 & -1.2528 & -0.0713 & - & - & - \\
\hline & \multirow{4}{*}{$\mathrm{H}$} & $\mathrm{k}_{0}$ & 1.0068 & 0.9770 & 1.0367 & 0.9977 & 0.9777 & 1.0178 \\
\hline & & $\mathrm{k}_{1}$ & 0.00113 & 0.00104 & 0.00121 & 0.00495 & 0.00475 & 0.00514 \\
\hline & & $\emptyset_{1}$ & 1.0972 & 0.4171 & 1.9545 & 0.6105 & 0.1047 & 1.1596 \\
\hline & & $\emptyset_{2}$ & -0.6475 & -1.3051 & -0.0645 & - & - & - \\
\hline & \multirow{5}{*}{ STPE } & $\mathrm{k}_{0}$ & 0.9194 & 0.3468 & 1.2735 & - & & - \\
\hline & & $\mathrm{k}_{1}$ & 0.00122 & 0.00073 & 0.00243 & - & - & - \\
\hline & & $\mathrm{k}_{2}$ & 0.0712 & -0.2859 & 0.6566 & - & - & - \\
\hline & & $\emptyset_{1}$ & -1.3378 & 0.3802 & 2.2722 & - & - & - \\
\hline & & $\emptyset_{2}$ & -0.6363 & -1.3533 & 0.0958 & - & - & - \\
\hline
\end{tabular}

UL-Upper Limit; LL-Lower Limit.

Table 3. Adjustment quality evaluators of the Lewis $(\mathrm{L})$ and Henderson $(\mathrm{H})$ models to the drying kinetic data of 'Prata' and 'D'água' banana cultivars at temperatures of $40^{\circ} \mathrm{C}$ and $70^{\circ} \mathrm{C}$, considering autoregressive errors of orders 1 and 2.

\begin{tabular}{cccccccc}
\hline \multirow{2}{*}{ Cultivars } & \multirow{2}{*}{ Models } & \multicolumn{3}{c}{$40^{\circ} \mathrm{C}$} & \multicolumn{3}{c}{$70^{\circ} \mathrm{C}$} \\
\cline { 3 - 8 } & & $\mathrm{R}_{\text {aj }}^{2}$ & RSD & AICc & $\mathrm{R}_{\text {aj }}$ & RSD & AICc \\
\hline Banana & $\mathrm{L}$ & 0.8680 & 0.0571 & -32.1767 & 0.5306 & 0.1612 & -36.8051 \\
'Prata' & $\mathrm{H}$ & 0.9796 & 0.0255 & -39.5113 & 0.9989 & 0.0101 & -55.0158 \\
\hline Banana & $\mathrm{L}$ & 0.9906 & 0.0218 & -39.6866 & 0.2163 & 0.1894 & -29.0181 \\
'D'água' & $\mathrm{H}$ & 0.9792 & 0.0309 & -35.7111 & 0.9984 & 0.0129 & -52.9628 \\
\hline
\end{tabular}



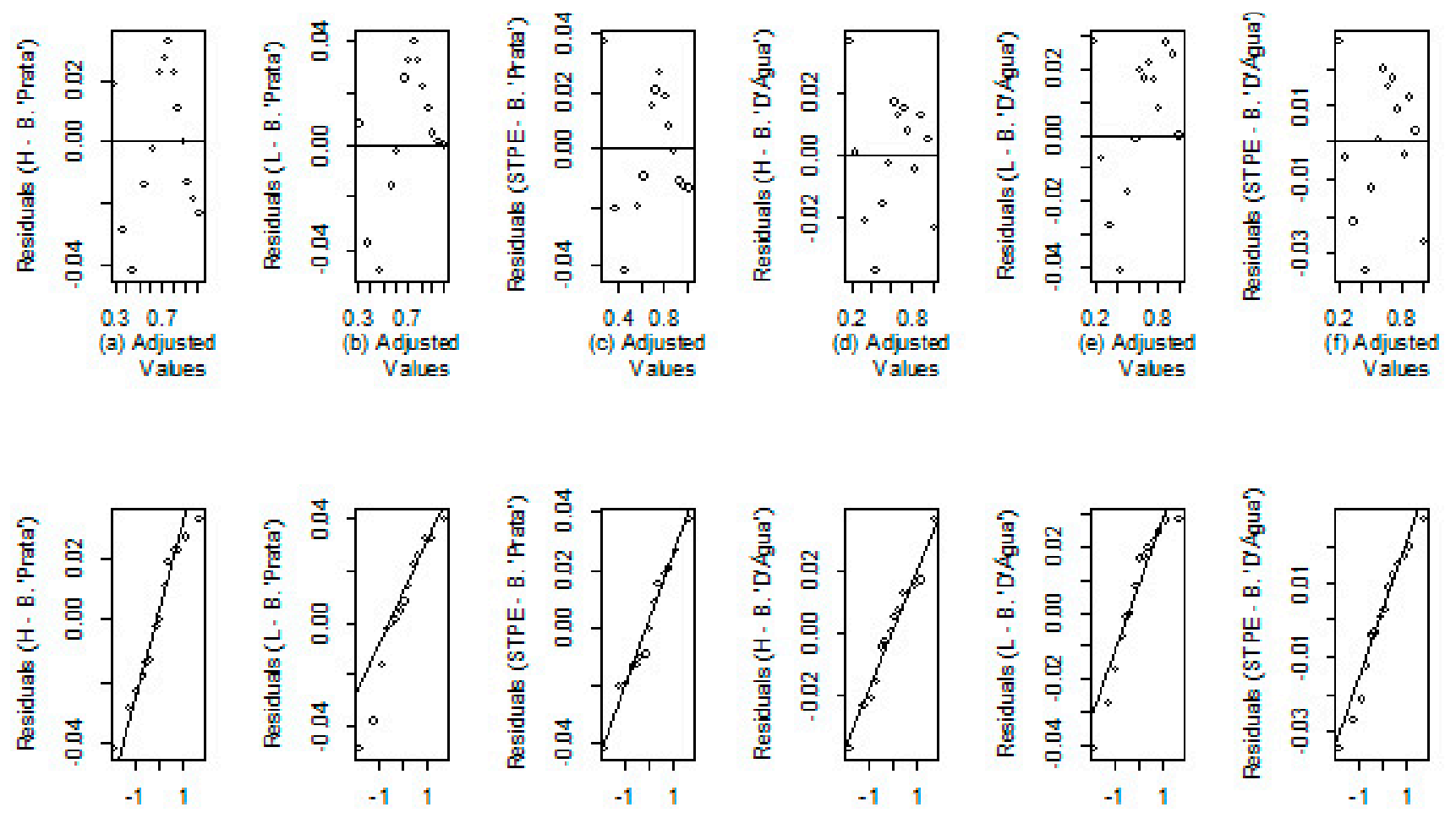

(g) Theoretical Anount

(h) Theorefical Amoun

(i)Theorefical Amount

(j) Theoretical Anount

(k)Theoretical A nount

(I)Theoretical Anount:

Figure 1. Residual analysis for the drying kinetics of 'Prata' and 'D'água' bananas at $40^{\circ} \mathrm{C}$, where (a), (b), (c), (d), (e) and (f) represent the adjusted values for residues, and in (g), (h), (i), (j), (k) and (l), the residual values relative to theoretical quantiles for the Henderson (H), Lewis (L) and Simple Three-Parameter Exponential (STPE) models.
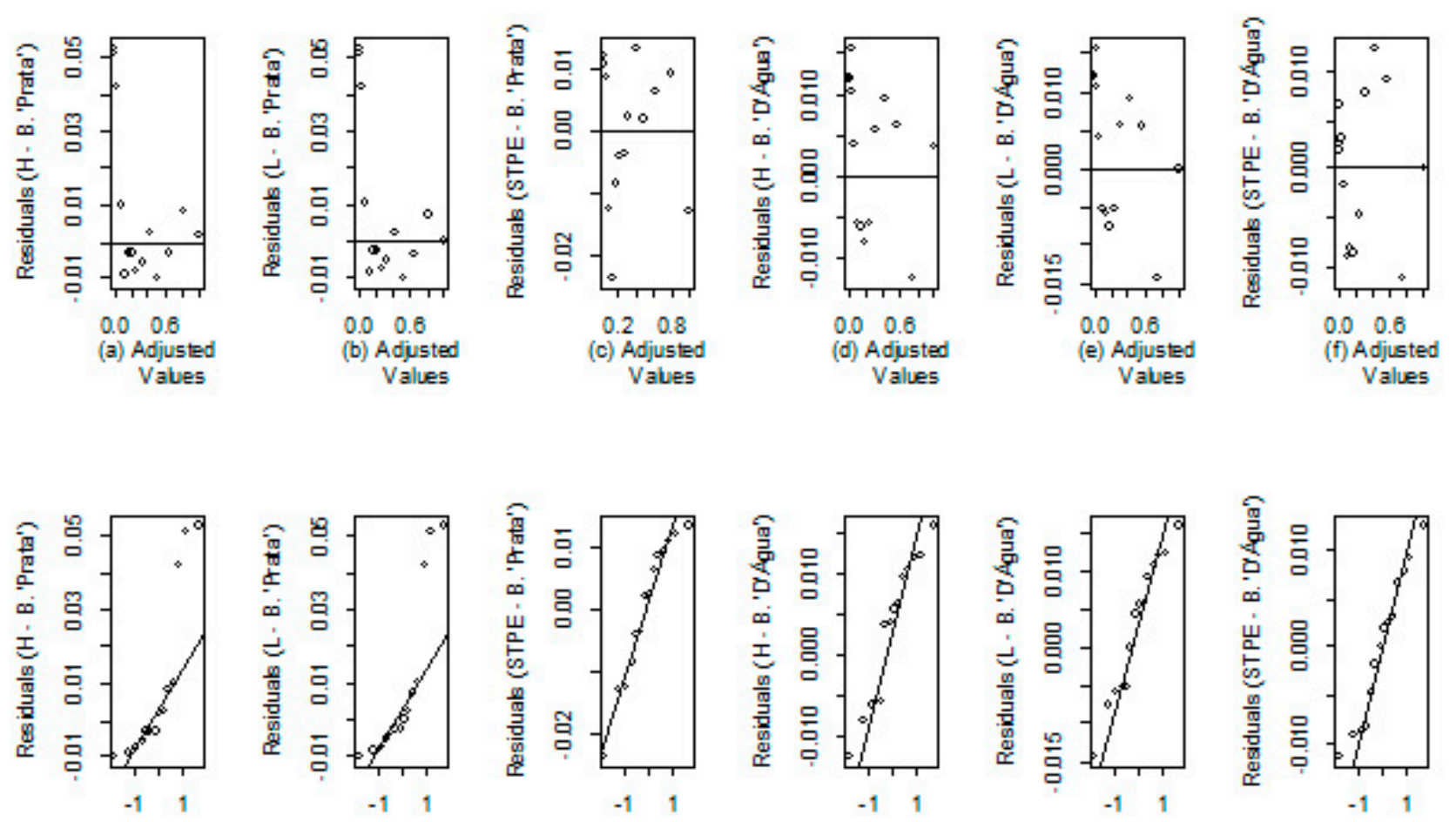

(g)Theoretical Anount

(h) Theorefical Amoun

(i)Theorefical Amount:

(j) Theoretical A nount:

(k)Theoretical Anount

(D)Theoretical A nount:

Figure 2. Residual analysis for the drying kinetics of 'Prata' and ' $\mathrm{D}$ 'água' bananas at $70^{\circ} \mathrm{C}$, where (a), (b), (c), (d), (e) and (f) represent the adjusted values for the residues, and in (g), (h), (i), (j), (k) and (l), the residual values relative to theoretical quantiles for the Henderson (H), Lewis (L) and Simple Three-Parameter Exponential (STPE) models. 


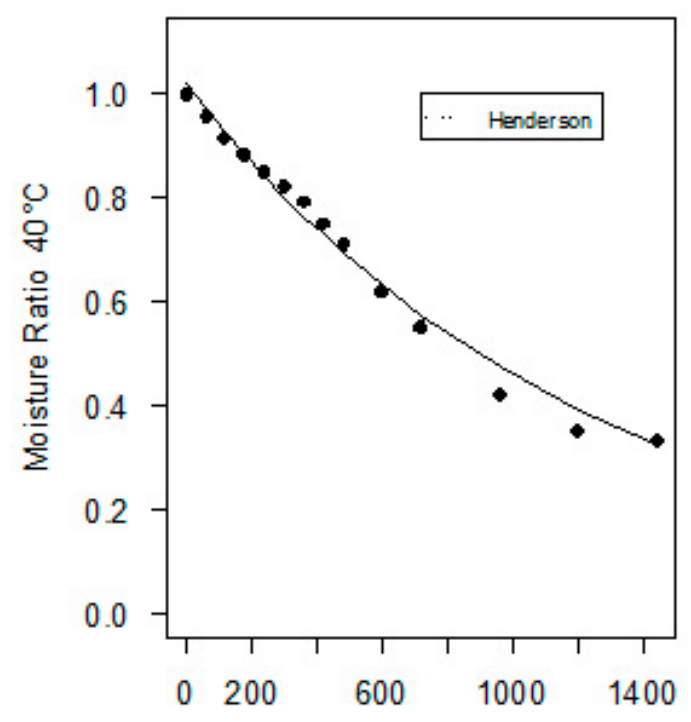

(a) Time (min)

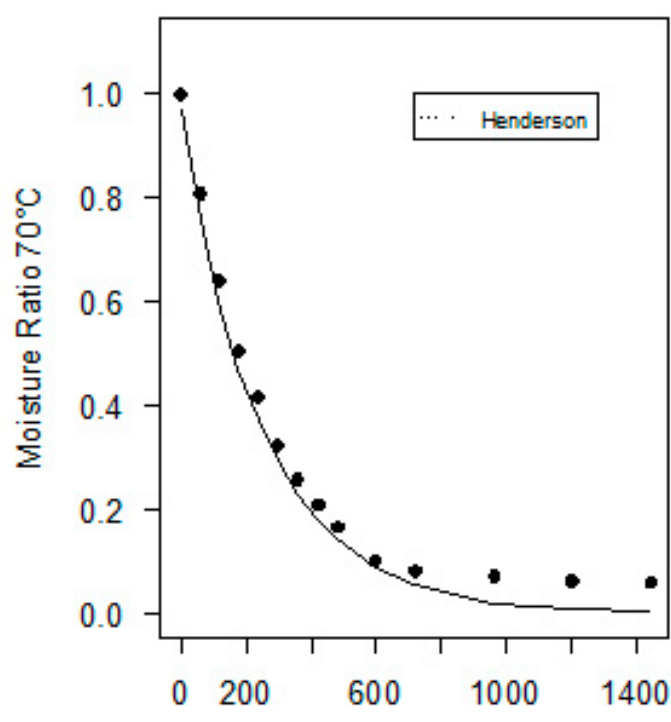

(b) Time (min)

Figure 3. Adjustment curves of the Henderson model for Moisture Ratio (MR) as a function of Time (s) to 'Prata' Banana drying kinetics data at $40^{\circ} \mathrm{C}$ and $70^{\circ} \mathrm{C}$ in (a) and (b) respectively.

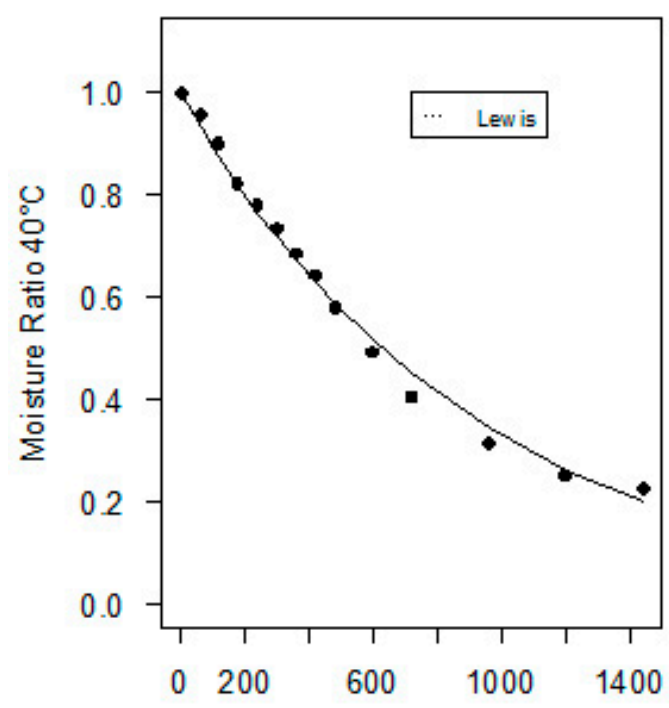

(a) Time (min)

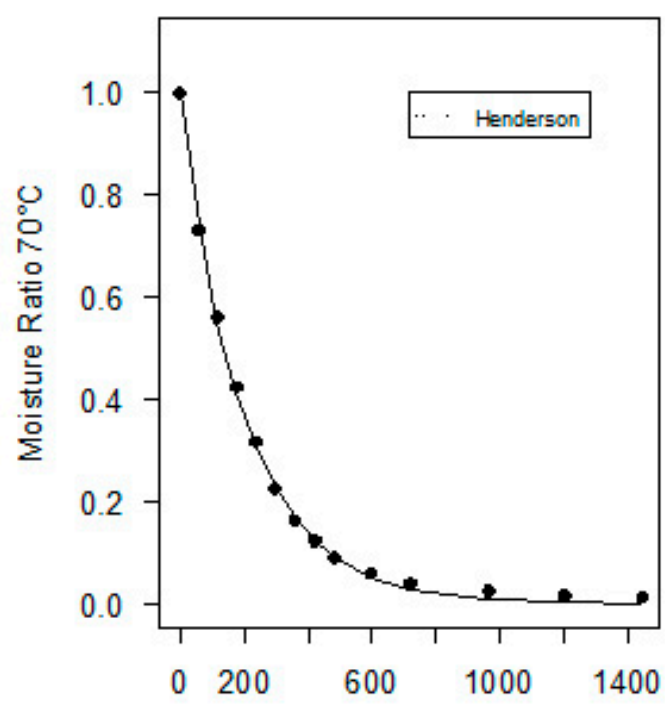

(b) Time (min)

Figure 4. Adjustment curves of the Lewis and Henderson models for the Moisture Ratio (MR) as a function of Time (s) to 'Prata' Banana drying kinetics data at $40^{\circ} \mathrm{C}$ and $70^{\circ} \mathrm{C}$ in (a) and (b) respectively. 


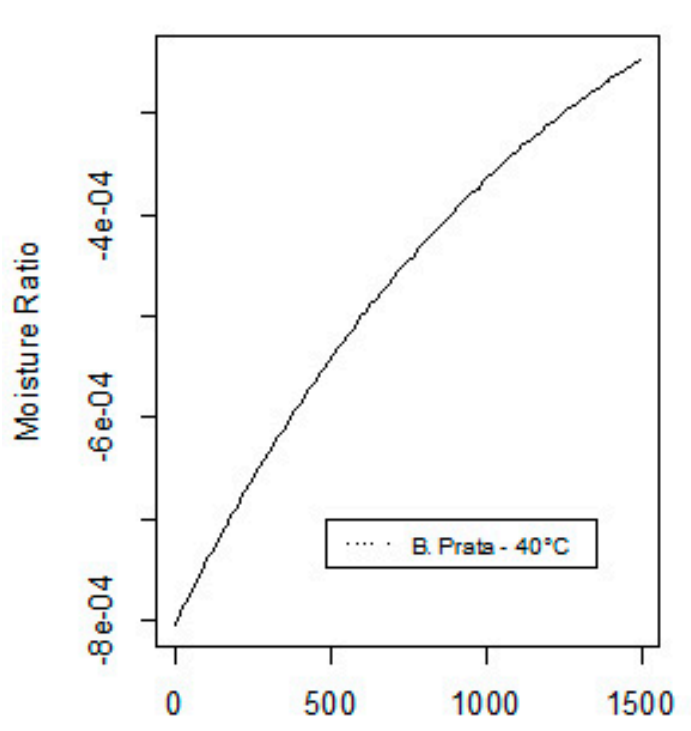

(a) Time (min)

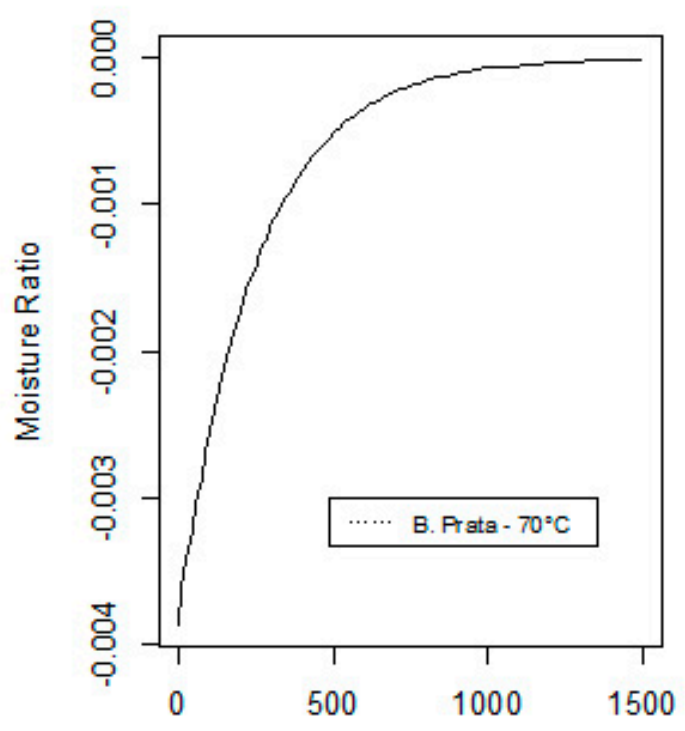

(a) Time (min)

Figure 5. Absolute drying rate for the adjustment of the Henderson's Moisture Ratio (MR) model as a function of Time (s), to 'Prata' banana drying kinetics at $40^{\circ} \mathrm{C}$ (a) and $70^{\circ} \mathrm{C}$ (b).

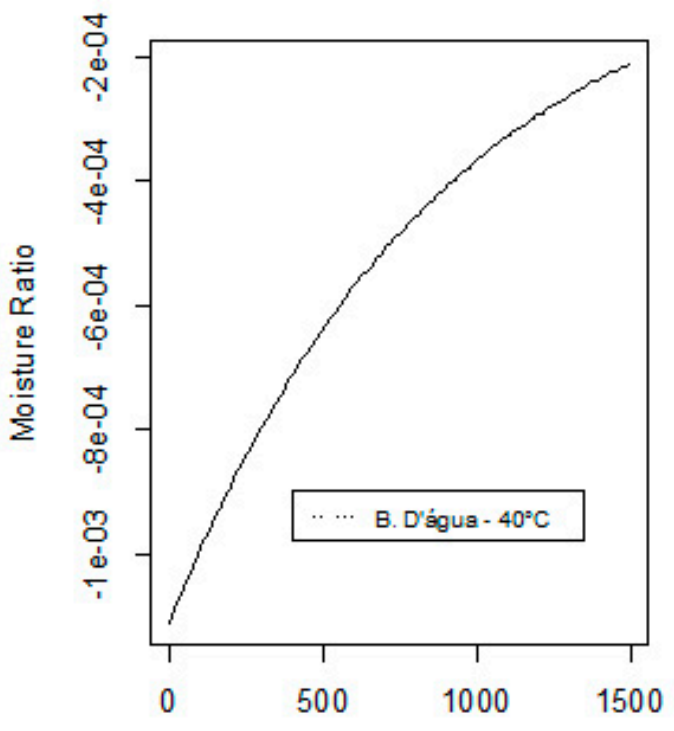

(a) Time (min)

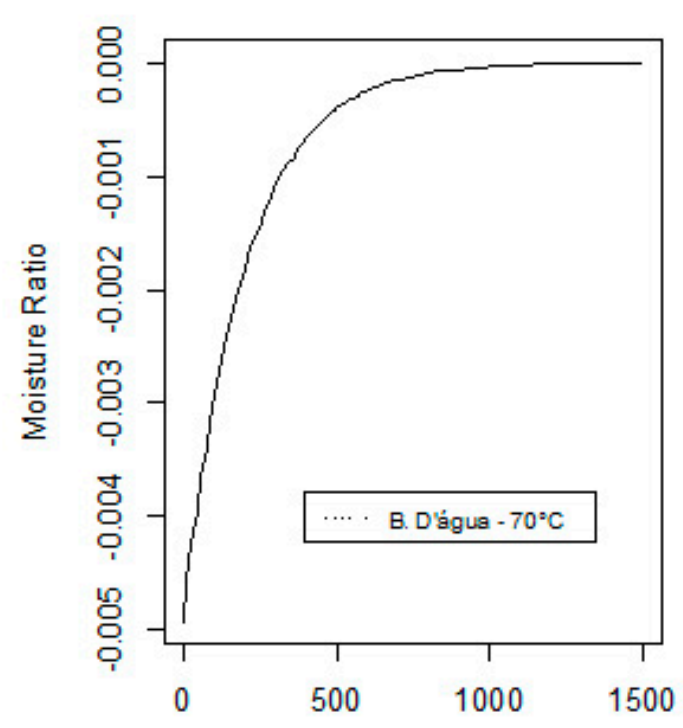

(a) Time (min)

Figure 6. Absolute drying rate referring to the adjustment of the Henderson model for the Moisture Ratio (MR) as a function of Time (s) to 'Prata' Banana drying kinetics data at $40^{\circ} \mathrm{C}$ and $70^{\circ} \mathrm{C}$ in (a) and (b) respectively. 


\section{Conclusions}

The Lewis, Henderson and Simple Three-Parameter Exponential models adjusted adequately to 'Prata' and 'D'água' banana drying data at temperatures of 40 and $70^{\circ} \mathrm{C}$, while the Fick and Page models did not. The most suitable model to describe 'Prata' banana data was the Henderson model, considering first and second order autocorrelation $\left(\varnothing_{1}\right.$ and $\left.\emptyset_{2}\right)$ among residues at $40^{\circ} \mathrm{C}$ and first order at $70^{\circ} \mathrm{C}$. For 'D'água' cultivar, the best models were Lewis considering first and second order autocorrelation $\left(\emptyset_{1}\right.$ and $\left.\emptyset_{2}\right)$ among residues at $40^{\circ} \mathrm{C}$ and Henderson considering first order autocorrelation at $70^{\circ} \mathrm{C}$.

The drying rates of 'Prata' bananas at temperatures of $40^{\circ} \mathrm{C}$ and $70^{\circ} \mathrm{C}$ were $0.00079 \mathrm{~g}$ of water $/ \mathrm{min}$ and $0.00400 \mathrm{~g}$ of water/min respectively and for ' $\mathrm{D}$ 'água' bananas, drying rates were $0.00111 \mathrm{~g}$ of water $/ \mathrm{min}$ and $0.00495 \mathrm{~g}$ of water/min, respectively. With the Absolute Drying Rate, it was observed that in one third of the drying period, there was $70 \%$ of moisture loss at $70^{\circ} \mathrm{C}$.

\section{Acknowledgments}

To the Federal University of Lavras (UFLA) for the development of the research and to CAPES and CNPq for the scholarship.

\section{References}

AKAIKE, H. A New look at the statistical model identification. IEEE Transactions on Automatic Control, New York, v.19, n.6, p.716-723, 1974.

ARAUJO, W.D.; GONELI, A.L.D.; CORRÊA, P.C.; HARTMANN FILHO, C.P.; MARTINS, E.A.S. Modelagem matemática da secagem dos frutos de amendoim em camada delgada. Revista Ciencia Agronomica, Fortaleza, v.48, n.3, p.448-457, 2017.

BORGES, A.L.; OLIVEIRA, A.M.G.; RITZINGER, C.H.S.P.; ALMEIDA, C.O. de; COELHO, E.F.; SANTOSSEREJO, J.A. dos; SOUZA, L .da S.; LIMA, M.B.; FANCELLI, M.; FOLEGATTI, M.I. da S.; MEISSNER FILHO, P.E.; SILVA, S. de O.; MEDINA, V.M.; CORDEIRO, Z.J.M. A cultura da banana. 3.ed. Brasília, DF: Embrapa Informação Tecnológica, 2006.

BORGES, S.V.; MANCINI, M.C.; CORRÊA, J.L.G.; LEITE, J.B. Drying kinetics of bananas by natural convection: influence of temperature, shape, blanching and cultivar. Ciência e Agrotecnologia, Lavras, v.35, n.2, p.368-376, 2011.
BORGES, S.V.; MANCINI, M.C.; CORRÊA, J.L.G.; NASCIMENTO, D.A. Secagem de fatias de abóboras (Cucurbita moschata, L.) por convecção natural e forçada. Ciência e Tecnologia de Alimentos, Campinas, v.28, p.245-251, 2008. Suplemento

BREUSCH, T.S.; PAGAN, A.R. A Simple test for heteroscedasticity and random coefficient variation. Econometrica, Chicago, v.47, n.5, p.1287-1294, 1979.

CANO-CHAUCA, M.; RAMOS, A.M.; STRINGHETA, P.C.; MARQUES, J.A.; SILVA, P.I. Curvas de secagem e avaliação da atividade de água da banana passa. Boletim CEPPA, Curitiba, v.22, n.1, p.121-132.

CARNEIRO, A.P.S.; MUNIZ, J.A.; CARNEIRO, P.L.S.; MALHADO, C.H.M.; MARTINS-FILHO, R.; SILVA, F.F. Identidade de modelos não lineares para comparar curvas de crescimento de bovinos da raça Tabapuã. Pesquisa Agropecuária Brasileira, Brasília, DF, v.49, n.1, p.5762, 2014.

Celestino, S. M. C. Princípios de secagem de alimentos. Planaltina: Embrapa Cerrados, 2010. p.51. (Documentos, 276)

COSTA, B.P.; AUGUSTO, C.; REGO, R.D.M. As várias cultivares de banana e a problemática de sua comercialização no município de Olinda Nova do Maranhão The various cultivars of banana and the problem of marketing in the municipality of Olinda Nova do Maranhão. Agropecuária Científica no Semiárido, Campina Grande, v.10, n.4, p.1-4, 2014.

FAOSTAT. Crops and trade: crops and livestok products. Rome: FAO, 2018. Disponível em: http://www.fao.org/ economic/est/est-commodities/bananas/en/. Acesso em: 27 nov. 2018.

FERNANDES, T.J.; MUNIZ, J.A.; PEREIRA, A.A.; MUNIZ, F.R.; MUIANGA, C.A. Parameterization effects in nonlinear models to describe growth curves. Acta Scentiarum Technology, Maringá, v.37, n.4, p.397-402, 2015.

FERNANDES. T.J.; PEREIRA, A.A., MUNIZ, J.A. Double sigmoidal models describing the growth of coffee berries. Ciência Rural, Santa Maria, v.47, 2017.

FURTADO, T. D. R.; MUNIZ, J. A.; SILVA, E. M.; FERNANDES, J. G. Kinetics of drying of jabuticaba pulp by regression models. Revista Brasileira de Fruticultura, Jaboticabal, v.41, n.1, 2019. 
GONÇALVES, J.Q.; SILVA, M.A.P. da; PLÁCIDO, G.R.; CALIARI, M.; SILVA, R.M.; MOURA, L.C.; SOUZA, D.G. Secagem da casca e polpa da banana verde (Musa acuminata): Propriedades físicas e funcionais da farinha. Global Science and Technology, Rio Verde, v.9, n.3, p.62-72, 2016.

GOUVEIA, J. P.G.; ALMEIDA, F. A. C.; FARIAS, E. S.; SILVA, M. M.; CHAVES, M. C. V.; REIS, L. S. Determinação das curvas de secagem em frutos de cajá. Revista Brasileira de Produtos Agroindustriais, Campina Grande, n.1, p.65-68, 2003. Volume especial

GUEDES, M.H.P.;MUNIZ, J.A.; PEREZ, J.R.O.; SILVA, F.F.; AQUINO, L.H.de; SANTOS, C.L. dos. Estudo das curvas de crescimento de cordeiros das raças santa Inês e bergamácia considerando heterogeneidade de variâncias. Ciência e Agrotecnologia, Lavras, v.28, n.2, p.381-388, 2004.

IBGE - Instituto Brasileiro de Geografia e Estatística. Produção agrícola aunicipal 1974 - 2017. Rio de Janeiro, 2018. Disponível em: https://sidra.ibge.gov.br/ tabela/1613\#resultado. Acesso em: 11 dez. 2018.

LEITE, A.L.M.P.; SILVA, F.S. da; PORTO, A.G.; PIASSON, D.; SANTOS, P. dos. Contração volumétrica e cinética de secagem de fatias de banana variedade Terra. Pesquisa Agropecuária Tropical , Goiânia, v.45, n.2, p.155-162, 2015.

MADUREIRA, I. A.; FIGUEIRÊDO, R. M. F.; QUEIROZ, A. J. M.; SILVA FILHO, E. D. Cinética de secagem da polpa do figo-da-índia. Revista Brasileira de Produtos Agroindustriais, Campina Grande, v.13, p.345-354, 2011. N. especial

MAZZINI, A.R.de A.; MUNIZ, J.A.; AQUINO, L.H.de; SILVA, F.F. Análise da curva de crescimento de machos Hereford. Ciência e Agrotecnologia, Lavras, v.27, n.5, p.1105-1112, 2003.

MORETTIN, P.; TOLOI, C. Análise de séries temporais. São Paulo: Editora Edgard Blücher, 2004. 535 p.

MOTA, R.V. da. Avaliação da qualidade de banana passa elaborada a partir de seis cultivares. Ciência e Tecnologia de Alimentos, Campinas, v.25, n.3, p.560-563, 2005.

MUIANGA, C.A.; MUNIZ, J.A.; NASCIMENTO, M.da S.; FERNANDES, T.J.; SAVIAN, T.V. Descrição da curva de crescimento de frutos do cajueiro por modelos não lineares. Revista Brasileira de Fruticultura, Jaboticabal, v.38, n.1, p. 22-32, 2016.
MUNIZ, J.A.; NASCIMENTO, M da S.; FERNANDES, T.J. Nonlinear models for description of cacao fruit growth with assumption violations. Revista Caatinga, Mossoró, v.30, n.1, p.250-257, 2017.

NOMURA, E.S.; DAMATTO JUNIOR, E.R., FUZITANI, E.J., AMORIM, E.P., SILVA, S. de O. Avaliação agronômica de genótipos de bananeiras em condições subtropicais, Vale do Ribeira, São Paulo - Brasil. Revista Brasileira de Fruticultura, Jaboticabal, v.35, n.1, p.112-122, 2013.

PRADO, T.K.L.do; SAVIAN, T.V.; MUNIZ, J.A. Ajuste dos modelos Gompertz e Logístico aos dados de crescimento de frutos de coqueiro anão verde. Ciência Rural, Santa Maria, v.43, n.5, p.803-809, 2013.

R DEVELOPMENT CORE TEAM. R: a language and environment for statistical computing. Vienna: $\mathrm{R}$ Foundation for Statistical Computing, 2012.

RIBEIRO, T.D.; PACOPAHYBA, R.W. de M.; MORAIS, A.R. de; MUNIZ, J.A. Description of the growth of pequi fruits by nonlinear models. Revista Brasileira de Fruticultura, Jaboticabal, v.40, n.3, p.e949, 2018 b.

RIBEIRO, T.D.SAVIAN, T.V.; FERNANDES, T.J.; MUNIZ, J.A. The use of the nonlinear models in the growth of pears of 'Shinseiki' cultivar. Ciência Rural, Santa Maria, v.48, n.1, e20161097, 2018a. Disponível em: http://www.scielo.br/scielo.php?script=sci arttext\&pid $=\mathrm{S} 0103-84782018000100202$. Acesso em: 18 jan. 2018.

SALOMÃO, C.; SIQUEIRA, D. L. de; LINS, L. D. L. de; CECON, P.R. Crescimento e produção da bananeira (Musa spp. AAB) 'Prata-Anã', oriunda de rizoma e micropropagada. Revista Ceres, Viçosa, MG, v.63, n.3, p.340-347, 2016.

SANTOS, L.O.; MARTINS, R.N.; CASTRICINI, A.; RODRIGUES, M.G.V.; DIAS, M.S.C. "Prata-Anã" banana conservation at $12^{\circ} \mathrm{C}$ and $14^{\circ} \mathrm{C}$ under controlled atmosphere. Científica, Jaboticabal, v.45, n.1, p.57-63, 2017.

SARI, B. G.; LÚCIO, A. D.; SANTANA, C. S.; SAVIAN, T. V.Describing tomato plant production using growth models. Scientia Horticulturae, Amsterdam, v.246, p.146-154, 2019.

SAS - Statistical Analysis System Institute. SAS procedures guide for computers. $6^{\text {th }} \mathrm{ed}$. Cary, 2018. v. 3,373 p. 
SAVIANT.V.; MUNIZ, J.A.A Study of in situ degradability: heterogeneity of variances and correlated errors. Scientia Agrícola, Piracicaba, v.64, p.548-554, 2007.

SHAPIRO, S.S.; WILK, M.B. An analysis of variance test for normality. Biometrika, Cambridge, v.52, n.3, p.591-611, 1965.

SILVA, D. C.; LIMA, M. F.; VÉLEZ, H. A. V.; SANTANA, A. A. Study of modeling cupuaçu pulp drying kinetic in biopolymers production. Revista Brasileira de Iniciação Científica, Itapetininga, v.4, n.3, p. 50-572017.

SILVEIRA, S.C. ; MUNIZ, J. A.; SOUSA, F.A. ; CAMPOS, A.T. . Modelos não lineares ajustados à produção acumulada de biogás provenientes de camas sobrepostas de suínos. Revista Agrogeoambiental, v. 10, p. 91-103, 2018.

SILVEIRA, F. G.DA; SILVA, F. F. E; CARNEIRO, P.L. S.; MALHADO, C. H. M.; MUNIZ, J. A. Análise de agrupamento na seleção de modelos de regressão nãolineares para curvas de crescimento de ovinos cruzados. Ciência Rural (UFSM. Impresso), v. 41, p. 692-698, 2011.
SOUZA, E. M. DE; MUNIZ, J. A.; MARCHI, G.; GUILHERME, L. R. G. Modelagem não-linear da extração de zinco de um lodo de esgoto. Acta Scientiarum. Technology (Impresso), v. 32, p. 193-199, 2010.

SOUZA, I.F. ; KUNZLE NETO, J.E. ; MUNIZ, J. A.; GUIMARÃES, R.M. ; SAVIAN, T. V.; MUNIZ, F.R.. Fitting nonlinear autoregressive models to describe coffee seed germination. Ciência Rural (UFSM. Impresso), v. 44, p. 2016-2021, 2014.

TBCA. Tabela brasileira de composição de alimentos. Versão 6.0. São Paulo: USP, FoRC, 2017. Disponível em: http://www.fcf.usp.br/tbca/. Acesso em: 27 nov. 2018.

ZEVIANI, W.M.; SILVA, C.A.; CARNEIRO, W.J.DE O.; MUNIZ, J.A. Modelos não lineares para a liberação de potássio de estercos animais em latossolos. Ciência Rural, Santa Maria, v.42, n.10, p.1789-1796, 2012. 